\title{
O Teatro Negro como fonte de memória e identidade afro-descendente: Análise da peça Transegun, de Cuti
}

The Black Theater as a source for memory and identity of African origin: an analysis of the play Transegum, by Cuti

Emerson de Paula Silva ${ }^{1}$ 


\section{Resumo}

Este artigo pretende analisar a peça Transegum de Cuti a partir da ideia de uma construção da memória, estética, corporeidade e identidade afrodescendente de modo a procurar mostrar a importância deste texto como arquivo significativo da historiografia do teatro brasileiro e principalmente para o estudo da construção da identidade do negro no país.

Palavras-chave: Dramaturgia; teatro negro; identidade; memória; cultura afro -brasileira.

\section{Abstract}

This article intends to analyze the theater play Transegum by Cuti, in relation to notions such as Afro-Brazilian memory, aesthetics, corporeality and identity construction. Then we intend, by the dramatic analysis of the play, to show the importance of this text as part of the archive of Brazilian Theater History and as a source to investigate the identity constructions of black people in Brazil.

Keywords: Playwriting; black theatre; identity; memory; afro-brazilian culture.
ISSN: 1414.5731

E-ISSN: 2358.6958 
A corrente Teatro Negro ainda é algo em construção no país, porém, há uma produção dramatúrgica contemporânea considerável que reflete a relação com um passado ancestral dialogando com a atual situação do negro brasileiro. Atualmente, um dos maiores dramaturgos que discute o universo das relações raciais brasileiras a partir da experiência subjetiva afrodescendente é Luiz Silva, mais conhecido pelo pseudônimo Cuti.

Nascido em Ourinhos/SP em 31 de outubro de 1951, ele se formou em Letras (Português/Francês) pela Universidade de São Paulo. Mestre em Teoria da Literatura e Doutor em Literatura Brasileira pelo Instituto de Estudos da Linguagem da UNICAMP (1999/2005), foi um dos fundadores e membro do Quilombhoje Literatura, de 1983 a 1994, e um dos criadores e mantenedores da série Cadernos Negros, de 1978 a 1993. Suas peças têm sido lidas e representadas por grupos como Grupo Cabeça Feita, de Brasília, e Grupo Caixa Preta, de Porto Alegre, que encenou Transegun. O autor, que transita entre poesia, teatro, ficção e ensaios, retrata os dramas e situações a que todos estamos envolvidos, buscando na releitura da ancestralidade estabelecer relações com a contemporaneidade.

Transegum, publicada por Cuti em 2009, também tem como tema básico o processo de reconstrução da identidade do sujeito negro frente aos valores da cultura europeia. Zélia é negra e casada com Romildo, um rapaz branco. Zélia pertence a um grupo de teatro negro brasileiro empenhado na encenação de um espetáculo para o Dia da Consciência Negra. Mas o grupo enfrenta a dificuldade de conviver com a recente morte de um de seus principais integrantes. A substituição deste por um ator branco (Romildo) desencadeia uma crise identitária que tem como foco o questionamento da construção da memória étnica e cultural do grupo.

A peça Transegun de Cuti se estrutura em 3 atos, tendo cada ato um número específico de quadros cujas ações não seguem uma ordem cronológica. Passado e Presente se misturam no palco para juntos transmitirem o enredo da peça e se diferenciam para o espectador por meio de recursos de iluminação. Dentre os espaços de ação existentes encontramos o Clube Palmares (onde se desenvolve grande parte do texto), o cilindro, a cozinha e o espaço de memória. A temática do texto são as relações raciais brasileiras a partir da experiência subjetiva do afrodescendente, trazendo a discussão do nosso processo histórico, as contradições nas relações inter-raciais, os processos de consciência racial, a dramaturgia e as relações de poder nela existentes.

Faz-se pontuar, a partir da temática apresentada, a importância dos diferentes cenários utilizados:

- Clube Palmares: Exemplo de clube social onde acontecem bailes e ações de lazer e cultura. O potencial nominal do Clube nos remete ao Quilombo dos Palmares, local de abrigo, proteção e resistência dos negros em momento histórico brasileiro no que tange a luta contra a escravidão. Afirmação espacial da negritude. Local de proteção e também de articulação, ação, luta. Como se percebe na frase abaixo da placa com o nome do Clube proposta pelo autor como elemento cenográfico: Dance e Pense. 
- Cilindro: É um grande cilindro aberto e iluminado que gira em cena e que sempre traz a personagem Aldo. Funciona como o girar do tempo, o encontro entre passado e presente. Gera na peça a ideia de movimento, de como tudo é circular, de como tudo acaba tendo um eixo comum, um ponto a se retornar. A simbologia da circularidade africana. O cilindro na peça traz sempre a discussão da presença de Aldo, vivo ou morto, e o que a sua presença (viva ou não), gera em cada integrante do grupo teatral.

- Cozinha: é o espaço mais realista da peça no sentido físico, onde as discussões giram sempre em torno de diálogos que pontuam questões objetivas.

- Espaço da Memória: Ambiente com projeção de sombras de pessoas e outras formas não humanas. Sempre remete a cenas do passado que auxiliam o leitor/espectador no entendimento de questões intrínsecas ao texto. As cenas deste espaço antecipam um acontecimento ou apresentam o fato passado que gerou uma ação atual. É onde percebemos os dilemas no que tange à identidade racial e às marcas corporais/sociais que o processo identitário de cada personagem imprimiu nos mesmos.

Mesmo com todos estes espaços, a proposta é que a cenografia seja concebida de forma contemporânea, utilizando por exemplo o recurso de praticáveis.

O texto Transegun faz parte de uma coletânea de textos teatrais intitulada Dois nós na noite e outras peças do teatro negro brasileiro, editada pela Mazza Edições em 2009. Sobre esta obra e o autor, Augel nos informa que Cuti também:

Problematiza a questão da cor da pele na sua obra teatral, fazendo-a constituir o cerne de uma das suas peças, a que empresta título ao livro. Esse título, Dois nós na noite revela mais uma vez a sua forte preferência pela polissemia, tão frequente nas demais obras do autor (Augel, 2000, p. 316).

A escrita de Cuti aborda a identidade e a memória afro-brasileira apresentando-nos um olhar ampliado sobre a população negra no Brasil tornando sua obra um combate a representações já cristalizadas, apresentando uma textualidade "por dentro e por fora da instituída, construída por signos e cadeias semânticas que buscam valorizar o sujeito afro-descendente" (Oliveira, 2007, p.109). Sobre a questão de reinvenção da semântica na obra de Cuti, Augel aborda que:

Uma opção possível para o equilíbrio interior é aceitar-se a si mesmo e procurar valorizar justamente aquilo que durante séculos foi considerado depreciativo e humilhante. "Reinventamos, alterando profundamente a semântica da palavra negro", diz Cuti em $1985^{2}$. Invertendo a ordem estabelecida e tida como indiscutí-

2 Cuti(Luiz Silva). Cadernos Negros. 8 (1985) p. 21. 
vel, assumindo a sua condição de negro, afirmando em seus versos que "a palavra negro que muitos não gostam/ tem gosto de sol que nasce" ("A palavra negro"), o poeta incita o seu irmão de cor a "armar-se com a palavra negro/ ... / gritar com exuberância: negro / e perceber que o eco rompe o medo" ("Falar sem receio a palavra negro"). ${ }^{3}$ No exercício do reconhecimento - e da aceitação plena - de si próprio, Cuti vai ressaltando os traços da diferença para fazer emergir o seu eu e a sua singularidade, ao mesmo tempo em que direciona sua enunciação aos seus semelhantes, catapultando os estereótipos, assumindo como centro o considerado periférico, realçando com orgulho e altivez a sua alteridade. Cuti provoca, com sua fala múltipla, o prazer de ler e de ser, dando uma dimensão completamente nova à auto-representação do afro-descendente (Augel, 2000, p. 314-315)

Portanto o papel da linguagem para o autor é desconstruir estereótipos discutindo por vários ângulos a ideologia racista, mas pautando-se num discurso de emancipação. Seu texto é político, mas também é estético, onde o negro aborda sua realidade, reflete sobre a mesma, relembra um passado mas ressignificando no presente a palavra "negro", inserindo o afro-brasileiro como sujeito na história. A obra apresenta as seguintes personagens:

- Aldo: rapaz de corpo escultural. Belo de fisionomia. Só tem sentido real no quarto quadro do primeiro ato. Nos demais quadros tem função simbólica. Não é, portanto, visto pelas demais personagens.

- Kinda: moça de aproximadamente 24 anos. Usa óculos. Cabelo natural, crespo

- Zélia: esposa de Romildo. Jovial. Aparenta 18 anos. Cabelo natural, crespo.

- Bendelê: rapaz na casa de 30 anos.

- Zelão: rapaz aparentando a mesma idade de Kinda. Usa cabelo rastafári. Irmão de Helen. Filho de Dona Cida.

- Romildo: Rapaz branco, com idade próxima a 30 anos.

- Justino: forte e expansivo. Aparenta ser o mais novo do Grupo Viva.

- Helen: moça aparentando 30 anos. Irmã de Zelão, filha de Dona Cida. Usa cabelo alisado e comprido.

- Dona Cida: Mãe de Helen e Zelão. Senhora robusta, bem conservada.

Cabelo natural, crespo, bem trançado junto ao couro cabeludo.

Na peça, todas as personagens são negras, exceto por Romildo. As personagens da peça formam um grupo de teatro composto apenas por atores/atrizes negros/negras que precisam lidar com a morte de um de seus atores sendo este substituído por um ator branco. O diálogo entre consciência política, afetividade e ascensão social tensiona o grupo a conviver com a morte por meio da proposição da vida, simboli-

${ }^{3}$ Cuti. Flash crioulo sobre o sangue e o sonho. Belo Horizonte, Mazza

Edições, 1987, p. 26. 
zada pelo amor entre Aldo e Helen. A descrição das personagens aqui apresentadas conforme estabelecida pelo autor, se faz importante para entendermos a aparência externa de cada uma e o que esta aparência dialoga com o contexto dramatúrgico. Em relação às falas das personagens aqui citadas, é primordial também trazer estas referências, para melhor compreensão do conteúdo implícito nos diálogos. São por estas encruzilhadas que permeiam toda a estrutura dramática que transitaremos, utilizando as contribuições de Leda Martins e Ecléa Bosi.

Sobre o título da peça, Augel nos informa que:

Transegun dá um passo adiante na dramaturgia negra brasileira. Aí está presente toda a gama de temas que constitui o espectro específico da literatura afro-brasileira, mas vai muito além disso, incluindo elementos que tem a ver com a pessoa humana, independente da origem ou da inserção cultural ou étnica. De trama bem mais complexa do que as demais peças do teatro negro envolve o inter-relacionamento de todo o grupo, onde o amor e o ciúme desempenham um papel tão importante como o compromisso ideológico de denúncia da discriminação e afirmação identitária da própria "negrice". [...] O título da peça é de significado bastante instigante, talvez não completamente claro a primeira vista. A meu ver, trata-se de uma fusão entre "transe" e "egum". Egum é o espírito dos mortos e é justamente a presença de um morto, Aldo, o grande bailarino, que transita como principal elemento da peça dentro da peça. Sem outras alusões, a partir desse título Cuti insere a pedra angular da auto-identificação negra, a religião dos ancestrais, nesta sua importante peça (Augel, 2000, pp. 321-322).

A peça configura-se como uma dança de significados sobre a negritude onde cada cena apresenta uma ginga entre a identidade e a memória, apresentando ora recuos, ora aproximações, fazendo surgir uma coreografia única: a dança da morte (morte física, morte dos conceitos, morte da estabilidade e de verdades já cristalizadas).

\section{Encruzilhada 1: Narrador/Autor}

O texto utiliza a linguagem dramatúrgica para abordar a própria falta de uma dramaturgia negra. No enredo encontramos a discussão sobre o corpo como uma estética colocando em debate a existência de uma estética negra, mas também de uma estética branca, como no exemplo a seguir:

Zelão: Sabe, Kinda, para eu não ter de acumular direção e trabalho de ator, e talvez ser obrigado a mudar parte da dança e expressão corporal, achei legal ver se o Romildo podia substituir o Aldo.

Kinda - Pô, a gente passa uma semana sem ensaio, quando chega tem novidade?

Zelão - Você é contra?

Kinda - O Viva não é um grupo negro?

Zélia - Vai começar o racismo ao contrário.

Kinda - É só uma questão de coerência.

(Bendelê retorna do banheiro. Roupa humilde, pés no chão.)

Bendelê - Então, gente, dá pra começar?

Kinda - Tem novidade. O Viva agora tem um branco.

Zelão - Gente, vamos ter calma. Essa questão já foi discutida uma vez e foi difícil. Agora surgiu uma oportunidade prática pra gente testar o grupo.

Bendelê - Espera aí, posso saber do que se trata? 
Kinda - O Romildo vai entrar no grupo.

Bendelê - (Para Zelão) - Por que, diretor?

Zelão - Vai substituir o Aldo.

Bendelê - Sinceramente eu não entendo. Você mesmo disse uma vez que

(imitando Zelão) "O corpo negro, por si só, é uma linguagem cênica. Daí a necessidade de fazermos um teatro negro com atores negros"...?

Zelão - O corpo do branco também é uma linguagem e não pode ser excluído do nosso teatro.

Bendelê: O corpo do branco é o sacrário, não é mesmo? A xoxota divina da sinhazinha. A sensualidade das capas de revista, a novela das oito, na televisão o tempo todo... Afinal, até a hóstia, que é corpo de Cristo, é branca. Veja, o corpo de Deus é branco!(Pausa, controlando-se) Tudo bem... Mas, você pintou o rosto de branco para dar resposta simbólica no grotesco da cena e para mostrar (Imitando Zelão) "metaforicamente que o branco no Brasil é só um desejo, uma casca, uma supremacia de fora. Atrás de tudo encontra-se o negro, como sustentáculo da economia, da cultura, e mesmo da epiderme embranquecida...?" Não foi isso que você tinha bolado para substituir a sua incapacidade técnica para dançar e sustentar a máscara no rosto? E estava tudo bem, ensaiado...? (p. 35-36).

O trecho em questão nos apresenta a discussão sobre o negro no teatro e a luta por este espaço. É a afirmação do negro na arte pela plasticidade negra e o uso dela com função de destaque. É o grupo de teatro negro contemporâneo reafirmando um ideal, dando continuidade e contribuição para a afirmação do negro no campo teatral brasileiro tentando diminuir a lacuna existente desde a criação do TEN (Teatro Experimental do Negro) no Brasil. O Grupo Viva é a extensão deste movimento mantendo a ligação histórica com o legado de Abdias do Nascimento, pois como afirma Uzel:

Para resgatar o legado africano no Brasil, o TEN rompeu estéticas e conceitos, debruçando-se de forma relevante sobre a negritude em seu valor intrínseco, sem resvalar para aspectos meramente pitorescos ou históricos da raça. Sua proposta não abrangia somente a formação de atores e diretores, mas também a criação de uma literatura dramática, na qual os negros fossem heróis e protagonistas de sua própria história, subvertendo a lógica da predominância branca nos palcos (2003, p. 13-14).

Nesta perspectiva, a presença de um ator branco desconfigura uma estética que ainda encontra-se em construção. Já não há mais a lógica colonizadora, mas se sabe de sua herança na desigualdade e no preconceito ainda vigentes nos dias de hoje. O teatro e o negro não são mais vistos como eram na época colonial, sua dramaturgia ainda é algo buscado pelo Grupo Viva. Os atores querem se ver representados no cenário teatral de forma igualitária, sem estereótipos. Por isso a criação de um grupo que os represente. Significa o negro ter destaque dentro do contexto social da trama com importância e conflito. Que o conflito seja advindo de seu olhar para com o mundo e não do olhar do homem branco para o homem negro. O teatro negro atual apresentado pelo Grupo Viva prioriza a autoestima e a valorização da população negra mesmo discutindo a identidade étnica do afro-descendente. Para alguns integrantes do grupo a presença de um ator branco no elenco e do mesmo estar desempenhando um personagem opressor reforça ao espectador o olhar de fora para com a negritude, como vemos no exemplo abaixo: 
Zelão: Fique frio. Se a coisa se refere ao visual da peça, tudo bem. Vamos discutir. Agora, se a discordância é pelo fato de o Romildo ser branco, então é uma outra coisa a ser analisada. Eu proponho que a gente vá por partes.

$[\ldots]$

Bendelê: Veja bem, pra mim, quanto ao Romildo, não tenho nada contra. Só acho que é preciso pensar no trabalho. Colocar um branco batendo em negro, de forma realista, é cair no lugar comum, que, na verdade, não constitui toda a realidade. Vamos só estar referendando o racismo e até mesmo o escravismo, segundo a visão dominante. Vai ser uma peça como a maioria do material ressurgido na época do Centenário da Abolição: tronco, gargalheira, navio negreiro, o negro sempre na pior... Isso só traz vergonha para o nosso pessoal, precisamos parar com isso! Daí que acho um caminho importante jogar com a simbologia (p. 39).

É o olhar de dentro, do negro para com o negro que o grupo pretende evidenciar em sua dramaturgia, em sua proposta estética. É também o olhar do negro para com o branco. É apresentar a forma negra de interpretar através de atores carregados de histórias, referências, identidades, conhecimentos adquiridos. É aliar na cena teatral o prazer estético e a reflexão, proporcionando ao espectador e consequentemente nos próprios atores não só a contemplação da vida mas a possibilidade de discutir sobre a mesma.

Todas as personagens, exceto Helen e D. Cida, são artistas de teatro e utilizam da linguagem artística com instrumento político. Mas ser profissional da Arte ainda é considerado uma profissão questionável no sentido de segurança financeira. Principalmente quando a este se atrela a transformação social. É o que percebemos nos exemplos a seguir:

Zelão - Vendi duas esculturas ontem. Ganhei mais que o salário. Dá pra ficar parado um mês produzindo. O dinheiro, depois dou pra senhora. Pago água, luz, telefone e imposto. Acho que dá.

D. Cida - Tá muito bom. Mas tem mês que não se vê nem sombra de dinheiro do seu bolso. Vai viver assim a vida inteira? Uma hora tem, outra fica a zero. Vai ficar sempre cavocando madeira e com esse negócio de teatro, e essas coisas de negro pra lá e negro pra cá?

$[\ldots]$

D. Cida - Quer é andar desse jeito, com este cabelo que dá impressão que não lava, todo mal arrumado...

Zelão - Ah, Dona Cida... Fazia tempo que a senhora não regulava meu visual. Vai começar de novo? ... Dá um tempo!...

D. Cida - Tempo, tempo, tempo... Você precisa é pensar em melhorar de vida, isso sim. Esse negócio de movimento não dá camisa a ninguém... (p. 68-69)

Zélia: Acho mesmo que a gente precisa ter mais maturidade pra fazer teatro. Não vamos começar com muita confidência, senão vira psicodrama. Não dá certo (p. 34).

Esta passagem do texto de Cuti reflete a condição do negro na arte, mas também a condição do próprio autor que traz no texto teatral a sua trajetória enquanto artista negro e sua contribuição para a manutenção de um Teatro Negro: Transegum traz o texto do negro não só inserindo o negro no texto. Cuti fala do outro remetendo a si. Essa posição enquanto narrador/autor perpassa sua obra como percebemos no poema "Meu atabaque nosso": 


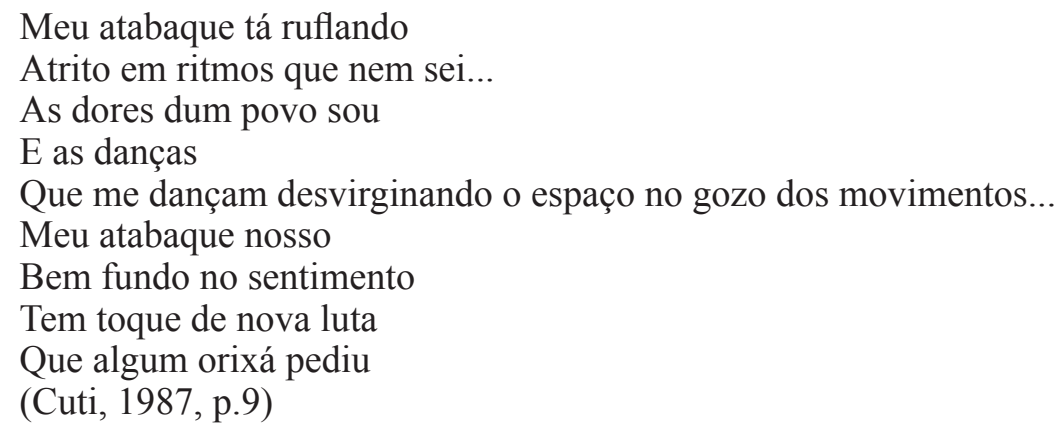

O autor transita entre o que contaram sobre o negro e o que o negro tem a contar sobre si sem ignorar suas marcas identitárias. O teatro apresenta-se então como uma possibilidade dos integrantes do Grupo Viva corporificarem outras sensações, ocuparem diferentes lugares e posições, transitarem entre reflexões, empoderar. O artista identificado com seu coletivo, refletindo as relações opressor-oprimido é uma discussão que permeia o enredo e conflito de cada personagem reverberando no processo identitário das mesmas.

Entender a construção de uma identidade consiste em analisar o processo histórico-pessoal de cada indivíduo e o diálogo deste processo com o ambiente. Identidade é um conceito então que abrange duas dimensões: a pessoal e a social. A identidade social surge do processo de identificação do indivíduo com aqueles considerados importantes em sua socialização. O indivíduo constrói a sua identidade através dos vários grupos de que faz parte, como a família, os amigos ou a escola, desempenhando papéis diversificados. É este o papel do Grupo Viva para cada integrante do mesmo.

Sabe-se que um dos caminhos de fortalecimento da identidade e sua alteridade é a arte. São de livres expressões as manifestações artísticas, as quais contribuem com o desenvolvimento do indivíduo por proporcionarem a transposição do processo de aprendizagem para a vida diária. Portanto, o Grupo Viva é uma forma de valorização da cultura negra através da arte e um espaço de discussão sobre o preconceito e o racismo tão camuflado no Brasil devido ao mito da democracia racial, uma vez que:

\footnotetext{
Os negros tendem a ver sua história como sucessão de três grandes capítulos: a rebeldia, a marginalização e a luta contra o racismo. Como toda visão do passado, esta é, naturalmente, parcial e ideológica - não se trata do passado objetivo, até onde se pode falar disso, mas da percepção do passado desde um certo ângulo do presente. Uma súmula da história do negro no Brasil - ou do negro brasileiro, ou ainda, do brasileiro negro - deveria, portanto, começar pela atualidade, desvelando as condições e maneiras pelas quais o negro percebe a sua história (Santos, 1978, p.88-89).
}

O Grupo Viva enquanto movimento promove essa revisão. Resistir através da arte é lutar de forma expressiva e reflexiva. O Grupo Viva enfrenta dificuldades de inserção social e apoio público, entretanto, tudo aquilo que poderia ser motivo de impedimento de suas ações passa a ser mais um complemento que argumenta a resistência. 
Seja através das irmandades religiosas, das religiões afro-brasilerias, do quilombo, das revoltas e rebeliões históricas, da imprensa negra, dos grupos de reivindicação e protesto, do Movimento Negro Unificado ou dos grupos culturais afro, o negro nunca foi agente passivo na construção de sua história e/ou da nossa história. O resgate cultural é também uma das ferramentas de resistência, pois:

Para o Movimento Negro o reconhecimento histórico não é apenas uma forma de valorizar a participação negra na construção da democracia no Brasil, mas, sobretudo, tem uma meta fundamental para ser atingida: adubar o árido terreno da cidadania brasileira e mostrar que a luta contra o racismo deve ser incorporada por todos aqueles que buscam um mundo mais plural e eticamente múltiplo e onde as organizações negras inscrevem-se no âmbito dos movimentos sociais que se insurgem como novos atores comprometidos com o desenvolvimento humano de modo coletivo (Cardoso, 2002, p.219).

É por questões como essas que a entrada de um ator branco no Grupo suscita discussão e reavaliação pois a peça se passa num momento contemporâneo, quando temos o negro assumindo papéis de autonomia, mas ainda resistindo no que tange à luta por ações afirmativas frente à elite branca. Os integrantes do Grupo Viva utilizam o teatro como elemento de diálogo com o mundo buscando a realização de seus desejos. Para tanto, a obra apresenta personagens pensantes, inteligentes e atuantes sócio politicamente. Dessa forma o próprio texto teatral encenado pelo Grupo Viva apresenta uma complexa rede de signos tecendo diferentes olhares. O teatro discute o teatro. Cuti ecoa Abdias, mas revela outras possibilidades do discurso do seu antecessor, ressignificando o próprio olhar afro-brasileiro, pois quando se volta para o "passado é para buscar nele o que se relaciona com suas preocupações atuais". (BOSI, 1994, p.76)

Cuti narra o que já foi ouvido/lido, imprimindo um registro textual que amplia o olhar sobre a cultura africana no Brasil. Seu texto reverbera a herança ancestral, colocando em movimento a relação com as origens, fazendo com que o autor imprima nas palavras ressignificações e reflexões, dando à memória uma função social, abrindo a encruzilhada do lembrar/esquecer sendo a mesma um momento de:

Desempenhar a alta função da lembrança. Não porque as sensações se enfraquecem, mas porque o interesse se desloca, as reflexões seguem outra linha e se dobram sobre a quintessência do vivido. Cresce a nitidez e o número das imagens de outrora, e esta faculdade de relembrar exige um espírito desperto, a capacidade de não confundir a vida atual com a que passou, de reconhecer as lembranças e opô-las às imagens de agora (Bosi, 1994, p. 81).

\section{Encruzilhada 2: Por dentro/por fora}

A personagem Kinda está presa à representação sobre a cor da pele - a ideia do preconceito rege sua vida, suas ações, suas relações com as outras personagens como vemos nos exemplos a seguir:

Zélia: Mas, você acredita no amor?

Kinda: Claro! Acredito, sim. De negro para negro. Mesmo porque acho que é muito tempo de humilhação em cima da gente para que o branco esqueça. O subconsciente fica comprometido. Vai dizer que 
ele nunca chamou você de "minha negra"?

Zélia: Não, o Rô me chama de "minha neguinha". E é com carinho.

Kinda: Será que lá no fundo ele não está chamando a mucama? Minha mãe conta que ela conheceu um casal, ele negro ela branca. Isso no interior.

Quando eles quebravam o pau - porque o cara era desses acostumados a resolver tudo na porrada - diz que ele dava nela de cinta. E, quando ela cansava de xingar ele de nego filho-da-puta, aí ela berrava pra todo mundo ouvir: "A sola do meu pé é mais limpa que a tua cara!" Aí, então, o couro comia mesmo. Zélia: E se eu falar pra você que estou com o Rô há um ano e nunca a gente brigou? Aliás, se estou aqui hoje no Viva, não é só por minha vontade, não. O Rô é o grande responsável pela minha negritude, o cara que mais me incentivou a me assumir. E de mais a mais é o tipo da pessoa que enfrentou família e tudo por minha causa. (p.28-29) Kinda: [...] Você sabe, todo branco é racista até que prove o contrário (p.40).

Kinda ainda se debate com a questão da cor da pele e do estereótipo negativo da cor negra em nossa sociedade. Mas Zélia e Romildo buscam um outro tipo de relação, visando "seguir em frente" a partir do que marcou o passado histórico dos negros:

Zelão: Não. Eu também não estou interessado. Pra mim tanto faz. Na certa deve ser algum branco. Vai ver que é por isso que ela não quer falar. Mulher negra... Depois vocês querem argumentar que homem negro quando sobe na vida fica atrás de branca...

Zélia: Eh, meu! Está me ofendendo...

Zelão: Desculpe, Zélia. Você é outro papo. Não fica com todo aquele j eito da Helen de fazer apologia da mestiçagem, melhora da raça... É dose!... (p. 34).

Helen, outra personagem, permanece no conflito questionando não só a si, mas todo o movimento negro, trazendo como elemento de indagação novamente a estética:

Aldo: Lá vai: é negra, se sente negra, tem vergonha de ser negra? Se nega?

Helen: Cruel!

Aldo: Enquanto a vida passa tudo se "esclarece"... Não é?

Helen: Não sei responder. Mas quase gostei.

Aldo: O machãozinho não deixou?

Helen: Não sei... Talvez. Mas, acho que não é preciso lembrar. Sou negra apenas quando lembro. Ou me fazem lembrar. Como você, agora.

No mais, tenho dúvidas. Acho a nossa gente muito parada, muito submissa diante do branco...

Aldo: Detalhe: não sou da sua gente, hein!

Helen: Falo duma maneira geral, desse pessoal que não se impõe. O que adianta ficar fazendo movimentozinho negro? O negócio é ir à luta, vencer, ocupar os espaços... (pp.54-55)

Helen: (...) Eu até hoje não entendi, nem aceito é essa situação que me divide em duas. Uma antes e outra depois da sua fase de militante do Movimento Negro. Como você conseguiu me forçar a isso? Eu me dividi, sabia? Uma ama você e a outra odeia. Isso desde que começou aquela encheção por causa do cabelo, que eu tinha que me assumir, você lembra? Bendelê: Isso não importa mais. O problema agora é outro...

Helen: É o mesmo. Você não engole minha opção de me livrar do complexo de raça. Eu sei que é isso. Você quer continuar com isso. Quando eu abri o coração... Ou melhor, comecei a abrir, você... 
Helen: Você precisa me respeitar.

Bendelê: Como respeitar uma pessoa que não se respeita?

Helen: Disse que ia cortar. Mas não consigo pensar em ter outro tipo de cabelo.

Bendelê: O seu cabelo.

Helen: Eu morro de vergonha só de imaginar, sabia? Não quero usar o cabelo duro e pronto!

Bendelê: Crespo! Você tem cabelo crespo. Quem inventou esse negócio de duro foi o racismo a brasileira, essa doença que injetaram no seu sangue (p.83 - 85).

Helen apresenta na sua rejeição à pele negra e ao cabelo encarapinhado, uma característica de autodesvalorização. Não assumir sua aparência e preferir estereótipos de beleza identificados com o tipo físico de pele branca indicam a dificuldade da personagem em se identificar com seu grupo de origem, tendo no seu "Ideal de Beleza" a necessidade de possuir cabelo liso, símbolo de sua auto-aceitação. Na questão capilar encontramos um processo doloroso de busca da própria identidade, da própria negritude. Helen está em conflito com sua auto-imagem e somente resolverá isso quando ela realmente voltar a si, a sua trajetória, a trajetória da raça a que pertence ao perceber em seu corpo, como Souza observa que?

[...] é a autoridade da estética branca quem define o belo e sua contraparte, o feio nesta nossa sociedade classista, onde os lugares de poder e tomada de decisões são ocupados hegemonicamente por brancos. Ele é quem afirma: "O negro é o outro do belo"(grifo do autor). É esta mesma autoridade quem conquista, de negros e brancos, o consenso legitimador dos padrões ideológicos que discriminam uns em detrimento de outros (Souza,1990, p.29).

Os trechos aqui citados corroboram com uma questão presente no discurso de todos os personagens e desvelado na fala de Kinda:

Kinda: Não odeio você. Só acho que a sua crise de ser negro não passou. Você não se vê como pessoa. Precisa se sentir negro-pessoa, indivíduo, e não como estigma. E daí se cuidar (p.63).

Nos trechos de cena aqui exemplificados vemos o reflexo da memória enquanto imagem e referência que estabelecem no corpo das personagens uma inquietação pelo que é visto e o que já foi vivido. Nesta perspectiva, a cor da pele das personagens promove um caminho de reflexão entre o que cada um é por fora (fenótipo) e do que falamos quando falamos em negro, ou seja, a palavra negro nos traz possibilidades de relações entre "cor e fenótipo, na experiência, na memória e lugar desse sujeito erigidos esses elementos como signos que o projetam e o representam" (Martins, 1995, p. 26). Estas personagens nos apresentam a visão ideológica para com o signo negro, carregado de conotações pejorativas, que fortalecem o racismo brasileiro, nos mostrando que:

O signo negro está intimamente identificado com um valor depreciativo nas mais diversas situações de fala brasileira, definindo uma posição social ou adjetivando um grupo racial e uma cultura. "Um dia negro", "a ovelha negra da família", por exemplo, são expressões que explicitam uma analogia entre o que é ser negro e o que é considerado ruim ou desagradável (Martins, 1995, p. 36). 
Expressões como estas colocam o negro como objeto, gerando, no caso de algumas personagens da peça, uma identificação à margem, sendo destacadas como diferentes produzindo nas mesmas, estigmas.

Os estigmas são criados quando percebemos que não estamos inseridos de alguma forma num contexto social. Estigmas são criados no contato com o outro. Sobre o estigma Loureiro (2004) explica que quando percebemos que a pessoa que conhecemos tem um atributo diferente do que nós imaginamos para ela, visto por nós como indesejável, passamos a considerá-la por esse atributo, ignorando todos os outros que ela possui. Ela fica, então, diminuída aos nossos olhos e seus atributos passam a ser um estigma.

Sabemos os atributos culturalmente associados à cultura negra e seus representantes. Esses atributos são retransmitidos a cada época. Muitas vezes reforçados ou reformulados. Mas sempre presentes. Fato é que os mestiços, ou chamados de mulatos, pardos ou morenos, encontram-se na ponte entre o ser, o querer ser e o que querem que eles sejam. Criam tonalidades de cor mas não reafirmam sua identidade étnica. O que interessa a esse grupo é uma identidade nacional.

Por isso, organizar-se enquanto grupo é uma forma de tentar organizar-se enquanto indivíduo. Cabe analisar como esse grupo é formado e quais perspectivas seus integrantes possuem. $O$ grupo teatral a que os personagens pertencem tem importância na formação do sujeito. É no contato com o grupo que esse indivíduo cria condições de se encontrar no todo, entendendo um drama particular: "a invenção e a circulação de uma imagem sombreada, de uma face invisível, de uma voz reprimida" (Martins, 1995, p.44).

As personagens tiveram a construção de suas identidades permeadas pelo tipo de relação com o próprio corpo e da experiência que este mesmo corpo lhes proporciona. Como corpo é memória, encontramos corpos que apresentam um racismo introjetado, capaz de gerar uma relação de conflitos entre o negro e seu corpo, entre o corpo e sua representação, entre o corpo que é visto e a imagem corporal desejada, criando no sujeito um "movimento persecutório de autodestruição, porque ele se torna incapaz de extrair, da relação com seu corpo e sua auto-imagem, qualquer pensamento ou enunciado de prazer" (Martins, 1995, p.156).

\section{Encruzilhada 3: Masculino/Feminino}

Noutra perspectiva temos em Transegum, um texto que confronta o leitor com temas como aborto, homossexualismo e AIDS. Após a morte de um dos integrantes, o grupo discute várias questões identitárias, num processo de sepultamento do amigo. Aldo aparece em cena, ora nas cenas do passado, esclarecendo fatos, dialogando com as personagens e nos colocando a par das questões abordadas na dramaturgia, ora no momento presente, como uma entidade que assiste a tudo mas não se comunica com os outros. A morte de Aldo reafirma a discussão sobre sexualidade, como percebemos nos exemplos abaixo:

Kinda: Não sei. Você já pensou no assunto? Será que ninguém do grupo transou 
com o Aldo. (p. 30)

Zélia: Eu sei que, quando uma pessoa morre, fica um buraco na vida da gente, mas, nem por isso vamos encher esse vazio com lama. (p.30)

Kinda: Já. E quer saber de uma coisa? Eu acho que a morte do Aldo está muito mal contada. (p.59.

Kinda: [...] É bom dar um tempo. De mais a mais eu acho que o importante agora é a gente se cuidar. Tem coisas entre nós que precisam vir à tona.

Zélia: Vai voltar com aquele papo?...

Kinda: Vou sim. Eu não tenho nada com a vida de ninguém. Mas acho que não dá mais pra ficar disfarçando. Gente, a morte do Aldo... Ninguém quer saber de conversar sobre isso. (p.78)

Kinda: A gente precisa se prevenir. Está todo mundo desconfiado e ninguém abre o jogo. Continua aqui no meio da gente o cadáver dele. Vocês ficam disfarçando. Quem garante que não houve transação sexual dentro do grupo.

Justino: Comigo não, violão! Nunca gostei de bicha. Negro bicha pra mim é porque foi educado por branco. Não me põe nesse bolo. (p.79)

Helen: Poeta? Influência do Aldo? (p.71).

Como já abordado, a ausência de Aldo traz à tona a discussão racial, que é também política: um branco ocupar o lugar de um negro num grupo de teatro formado inicialmente só por atores negros; e nos apresenta uma outra discussão: identidade sexual, já que Aldo se relacionou amorosamente/sexualmente com membros do grupo.

Neste ponto, analisamos uma temática que perpassa o texto analisado: a homossexualidade. Aldo faz parte do imaginário e da fantasia de todos integrantes do Viva: seu talento faz falta, seu charme faz falta, seu corpo(num sentido amplo) faz falta ao grupo. Aldo está mais presente no grupo após sua morte e é sua não presença que levanta questionamentos:

Kinda: [...] Mas o que eu quero saber é qual foi a sua ligação com o Aldo.

Romildo: Amigo. Muito amigo.

Kinda: Transa, muita transa?

Romildo: Você acha que homossexual só vive pra ter sexo? Ele era muito gente. Tinha sentimento e inteligência. Além do mais, sempre foi um cara preocupado com a cultura e com a evolução espiritual (p.94).

No exemplo apresentado Kinda ecoa o estereótipo em relação ao negro e sua sexualidade como aborda Reinaldo Damião em entrevista a Revista Raça (jan/2005), presidente da Associação do Orgulho GLBT - Gays, lésbicas, bissexuais e transgêneros:

Os homens negros são mais procurados pelo desempenho sexual, pelo tamanho do pênis e você passa a ser um objeto, porque valorizam apenas esse folclore, esse exotismo, e esta é também mais uma forma de preconceito, só que interno (Nascimento, 2005, p.60).

A sexualidade de Aldo o faz transitar entre o masculino e o feminino, aproximando a personagem de um diálogo com a ancestralidade, trazendo à cena a relação da religiosidade de matriz africana na vida de Aldo, como no exemplo a seguir:

Helen (rindo): Você acredita em Deus? 
Aldo: Eu não. Deus é macho, machão. Se não obedecer, ele senta o pau. E sem carinho nenhum. Ah, isso não faz bem nem no bumbum.

Acredito sim, no Espírito Santo, meu Pai Oxalá. Muita gente diz que é homem, mas não sabe que pro orixá tanto faz ogó(gesticula) quanto faz (gesticula) idi. Não vê a minha mãe de santo? Uma negrona gostosa que só.

Oxalá, minha filha! (p.54)

Helen: Eu sei, não sou boba. Toda porta tem um jeito certo de se abrir. O que digo é isso: você, por exemplo, está doente e parece o homem mais vivo do mundo.

Aldo: Fala "homem" com menos ênfase, por favor, E eu também não estou com essa bola toda, não.

Helen: Meu Oxumaré!

Aldo: Melhorou.

$[\ldots]$

Aldo: Está bem. Se não quer abrir o jogo pode ficar fechadinha. Sabe, nós femininas temos muita dificuldade de encontrar identidade. Não vê o tal

20 de Novembro? Zumbi! Machão. Em qualquer cartaz é aquela tora de homem. Vê se alguém descobriu o aniversário de morte de Dandara,

Acotirene... Ninguém. Ah, mas eu ainda vou montar um espetáculo com um Zumbi lindamente guei. Bem bicha mesmo! Pra fechar o comércio e paralisar o Movimento Negro machista. Quero dar risada até, de ver o corno do Justino tendo um infarto e o doutorzinho correndo para abrir processo "pela ofensa a um vulto histórico"...(ri)

$[\ldots]$

Aldo: Também. Você sabe que eu mudo de lado, né, minha filha?

Baixa o Zé do Pau Duro e eu não me conheço. Mas, agora, assim dodói, eu fico mais bichinha ainda (p. $55-57)$.

Cuti retrata em seu texto a presença do Candomblé, e como o culto aos Orixás, marca da cultura afro-brasileira, é sempre referendado numa dramaturgia direcionada ao Teatro Negro. É na encruzilhada entre masculino e feminino que Aldo nos apresenta sua característica a partir de seu Orixá guia, Oxumaré:

Oxumaré é a serpente arco-íris, que vive girando em redor do mundo. Durante seis meses é homem e nos outros seis meses é mulher, chamando-se Bessém. Como um Orixá da Terra, representa as riquezas escondidas no subsolo, mas também desempenha a função de levar a água de volta para o palácio de Xangô, no céu, a fim de garantir a perpetuação do ciclo das águas no planeta. No Candomblé, diz-se também que Oxumaré é o dono do som, das artes e da beleza. Sua principal característica é a dualidade, e talvez por isso ele seja um Orixá tão exigente e inconstante. Sob a forma de serpente é perigoso, mas sob a forma de arco-íris é benfazejo e extremamente belo. Seu eterno movimento impede o mundo de se desfazer. Para os sacerdotes do Ifá, Oxumaré é o mensageiro de Olodumaré. E, neste cargo, Oxumaré representa o pacto entre os deuses e homens. Isso lembra a passagem bíblica em que, após o dilúvio, Deus fez um arco-íris aparecer no céu para expressar Sua promessa de que o mundo não seria destruído pelas águas uma segunda vez. O arco-íris é o espectro visível da luz que manifesta os poderes de Orum(céu), uma ponte entre o humano e o divino, um fenômeno visível, plástico, imagem de uma divindade misteriosa e difícil de ser definida (Ligiero, 2004, p. 78).

Como o orixá que o rege, Aldo fala por gestos, representa o feminino, se oferece ao mundo. Porém há um avesso no corpo da personagem por representar o masculino viril. Aldo ressignifica em si um orixá sagrado se apropriando do mesmo para tecer uma narrativa que tem em seu conteúdo a transmissão de valores e os 
diferentes modelos de percepção de mundo. Essa duplicidade faz parte de seu caminhar regendo suas ações.

Podemos ainda dizer que Aldo nos traz valores africanos como o da tribo Dagara da África do Oeste pesquisada por Somé no que tange a imagem dos homossexuais como guardiães do portão:

As palavras "gay" e "lésbica" não existem na aldeia(Dagara). Temos, sim, a palavra "guardião". Os guardiães são pessoas que vivem no limite entre dois mundos - o mundo da aldeia e o mundo do espírito. [...] A maior parte das pessoas no Ocidente define a si e aos outros pela orientação sexual. Essa forma de ver destruiria o espírito dos guardiães. Eles conseguem fazer seu trabalho por causa de sua forte conexão espiritual. [...] Os guardiães estão na divisa entre os dois sexos. São mediadores entre os dois. Eles garantem que haja paz e harmonia entre mulheres e homens. [...] Simplesmente agem como a "espada da verdade e da integridade" (Somé, 2003, p.139).

Aldo personifica essa relação dupla, apresentando-se como uma encruzilhada entre as personagens: cada membro do grupo se vê diante de um espelho ao pensar sobre Aldo e o contato que cada integrante estabeleceu com o mesmo. Aldo é passagem: quando presença gerou em cada um a possibilidade de ir e voltar entre seus quereres; quando ausência abre espaços que serão ou não habitados pelas personagens. São estas diferentes percepções que a lacuna deixada por Aldo faz emergir em cada personagem.

\section{Encruzilhada 4: Ir/Vir}

Em meio a todas estas encruzilhadas, Helen está grávida e concebe ao mundo uma criança, que de acordo com a teia de relações apresentadas no texto pode ser fruto de sua relação com Aldo. É no nascer desta criança que percebemos a circularidade humana e os ensinamentos ancestrais africanos sobre maneiras de se relacionar, também apresentados por Somé, principalmente no propósito do nascimento:

\footnotetext{
[...] as crianças não pertencem completamente aos pais que lhes dão a luz; diz que elas usaram o corpo de seus pais para chegar, mas pertencem a comunidade e ao espírito (p.68).

O nascimento é a chegada de uma pessoa do outro lugar. A pessoa que está chegando deve ser saudada, deve sentir que chegou em um lugar onde há seres humanos que receberão suas dádivas (Somé, 2003, p.71).
}

A morte, assim como o nascimento, promove transformação e renovação. Em Transegum estes dois momentos funcionam como elo de uma cadeia de sentimentos: estar no mundo, afirmar-se nele, entender o mesmo, questioná-lo e transpô-lo. Esta circularidade é reforçada no grande cilindro cenográfico: o girar do tempo, o encontro entre passado e presente, a ideia de movimento, de como tudo é circular, de como tudo acaba tendo um eixo comum, um ponto a se retornar. A simbologia da circularidade africana. 
A criança que nasce ainda não ocupou seu lugar, mas é uma força em expansão. Será a partir das lembranças dos seus familiares que a mesma conduzirá sua experiência de vida. O nascimento da criança será o assunto que abarcará o Grupo Viva desvirtuando inicialmente o foco anterior que era a morte de Aldo. Porém, quanto mais presente o nascimento for, mais presente estará a memória de Aldo, uma vez que as histórias de cada personagem "inscrevem-se dentro da sua história, a de seu nascimento, vida e morte. E a morte sela suas histórias com o selo do perdurável" (Bosi, 1994, p. 89). A memória não anula nem reconstrói o tempo. Através dela temos o conhecimento do passado que ordena o tempo. O nascimento (significando esperança) e a morte (significando recordação) presentes no texto se constituem como fios que se cruzam a partir de um ponto inicial.

Percebe-se que nesta peça as personagens deixam de ser estereótipos para serem autênticos apresentando ao espectador seus conflitos identitários. No texto em questão as personagens não discutem apenas seus próprios dilemas mas sim o do outro e como o outro o resolve.

Augel nos apresenta uma conclusão da obra de Cuti em relação à produção dramatúrgica de um teatro negro ao longo de décadas:

O que pudemos observar foi que em nenhuma das peças dos escritores da década de 70 em diante é posta na boca das personagens qualquer fala que rebaixe ou diminua o afro-descendente. Em todas elas, as personagens afro-brasileiras se apresentam mais autênticas e convincentes, deixando o estatuto de estereótipo para adquirirem uma vida mais personalizada, mesmo que envolvidas e impregnadas pela ideologia do branqueamento, como a Helen, de Transegum. Nas peças de Cuti, a tensão é provocada pelo drama das personagens por terem que enfrentar a discriminação, por se verem vitimas ou estarem sofrendo pelo fato do companheiro não conseguir definir-se enquanto negro. (...) Vemos em Cuti que a sua autopercepção difere completamente da retratada pelos negros nas peças contidas na antologia Dramas para negros e prólogo para brancos. A dramaturgia afro-brasileira de Cuti está fincada no conhecimento e na vivência consciente da realidade racial brasileira, dos problemas dali decorrentes, do comportamento do homem e da mulher brasileiros reais e contemporâneos. Ultrapassando o simplismo maniqueista em geral encontrado nas outras peças, Cuti reintegra a comunidade afro-brasileira no mundo "normal", não a trata como algo fora do comum, externa aos demais acontecimentos, nem tão pouco idealiza o mundo negro, mostrando-o com as suas mazelas e suas contradições. Registra assim no microcosmo que escolheu uma amostra da sociedade tal como ela é, priorizando, sobretudo, a liberdade de lutar pelo próprio potencial, esforçando-se para refletir o afro-brasileiro na sua diversidade, seu caráter multifacetado, suas aspirações e suas frustrações (Augel 2000, p. 322-323).

A escrita de Cuti é memorial. Seu ponto de vista é desde dentro e desde fora tendo a história da formação brasileira como material cênico. Sua obra nos apresenta o passado de um povo e do passado que forma esse povo. Consegue abordar nossas dificuldades, fazendo com que sua dramaturgia transite em significados, funcionando como um registro significativo de nossas próprias representações, mostrando-nos as grafias inscritas em nossa memória. É um narrador capaz de trazer o signo negro como recurso estético e político entrelaçando tensões entre uma memória comum e uma memória de resistência, entre a sua voz e a voz do outro pois "seu talento de narrar lhe vem da experiência; sua lição, ele extraiu da própria dor; sua dignidade é 
contá-la até o fim, sem medo. Uma atmosfera sagrada circunda o narrador" (Bosi, 1994, p. 91).

Sua obra aborda problemas contemporâneos, mas com bases históricas: o percurso do coletivo negro descendente de escravos e as questões inscritas, ao longo do tempo, na trajetória da pele desse coletivo.

\section{É com o ponto de vista do próprio autor que fundamentamos o diálogo desse per- curso com a atualidade:}

Pensar o Teatro Negro-brasileiro implica em levar em conta a necessidade de se ampliar a inclusão de negros na plateia e reforçar o conteúdo transformador nos palcos. Isso exige um trabalho incessante com a dramaturgia existente para incentivar a produção futura. $\mathrm{O}$ texto dramático é a sustentação do amanhã. $\mathrm{O}$ acervo de peças que tragam personagens negras protagonistas e as apresentem em profundidade e complexidade humanas, no Brasil, carece de maior produtividade e disseminação. Peças podem ser garimpadas aqui e ali, entretanto, os tempos mudaram e o teatro não acompanhou a evolução da população negra. É, portanto, vesgo o olhar que só consegue visualizar o negro em grupo, negando-lhe a individualidade. É vesgo o olhar que não consegue detectar os dramas raciais entre negros, mestiços e brancos, e em cada um deles separadamente. $\mathrm{O}$ que se espera é que negro não seja sinônimo de estereótipo, representação de apenas uma classe social, movido tão-somente em direção ao passado dos tempos de escravização. Há muitos outros passados que não esse. É vesgo o olhar que só admite no palco negros arregalando os olhos como se fossem idiotas. Hoje, há companhias que buscam realizar e repensar suas produções, pois sem a autocrítica a criatividade fica tolhida em esquemas pré-estabelecidos. Quanto à forma, vesga a experimentação por mero diletantismo ou imitação desse ou daquele diretor, ator ou atriz. Um dos problemas sérios na Arte Negro-brasileira é tentar seguir o caminho que está dando certo para outros artistas. Olhar é fazer valer o ponto de vista, e, no caso, a visão negra a partir do coração, da experiência vivida. Afinal, a catarse da descendência africana precisa urgentemente ser feita para que a libertação interior se realize. ${ }^{4}$

Ir/Vir. Transegum inicia discutindo a morte de um integrante de um grupo teatral e termina com o nascimento de um provável integrante do mesmo, pois esta criança já nasce com toda uma trajetória em sua pele. O Grupo Viva não morrerá.

\section{Referências}

AUGEL, Moema Parente. A Fala Identitária: O Teatro Afro-Brasileiro Hoje. Afro-Ásia Universidade Federal da Bahia, n 24, 2000.

BOSI, Ecléa. Memória e sociedade: lembranças dos velhos. 3.Ed. São Paulo: Companhia das Letras, 1994.

\footnotetext{
${ }^{4}$ NEGRO OLHAR - II Ciclo de Leitura Dramatizada com Autores e Artistas Negros. Rio de Janeiro. Prospecto.
} 
CARDOSO, Marcos Antônio. O Movimento Negro em Belo Horizonte: 1978-1998. Belo Horizonte: Mazza Edições, 2002.

CUTI. Dois nós na noite e outras peças de teatro negro-brasileiro. 2. Ed., revista e ampliada. - Belo Horizonte: Mazza Edições, 2009.

Flash crioulo sobre o sangue e o sonho. Belo Horizonte: Mazza Edições, 1987.

LIGIERO, José Luiz. Iniciação ao Candomblé. Rio de Janeiro, Record: Nova Era, 2004.

e Dandara. Iniciação a Umbanda. Rio de Janeiro: Nova Era,

2000.

LOUREIRO, Stefânie Arca Garrido. Identidade étnica em reconstrução: A ressignificação da identidade étnica de adolescentes negros em dinâmica de grupo na perspectiva existencial humanista. Belo Horizonte: O Lutador, 2004.

MARTINS, Leda. Performances do tempo e da memória. O Percevejo - Revista de Teatro, Crítica e Estética, ano 11, no 12, 2003. Departamento de Teoria do Teatro. Programa de Pós-graduação em Teatro. Universidade Federal do Estado do Rio de Janeiro, UNIRIO.

A Cena em Sombras. São Paulo: Perspectiva, 1995.

Afrografias da Memória: O Reinado do Rosário no Jatobá. São Paulo: Perspectiva; Belo Horizonte: Mazza Eduções, 1997.

NASCIMENTO, Sônia. Liberdade para ser quem é. Revista Raça Brasil, São Paulo, ano 9, n. 82, jan. 2005.

OLIVEIRA, Luiz Henrique Silva de. A representação do negro nas poesias de Castro Alves e de [Luiz Silva] Cuti: de objeto a sujeito. Dissertação (Mestrado) - Universidade Federal de Minas Gerais, Faculdade de Letras. Belo Horizonte, MG: 187, 2007.

SANTOS, J.R. A luta organizada contra o racismo. In: Atrás do Muro da Noite (Dinâmicas das Culturas Afro-Brasileiras). Minc - Fundação Cultural Palmares. Cap. 1, p. 88 - 146, 2005.

SOMÉ, Sobonfu. O Espírito da Intimidade: ensinamentos ancestrais africanos sobre relacionamentos; tradução Deborah Weinberg, São Paulo: Odysseus Editora, 2003.

SOUZA, Neusa Santos. Tornar-se Negro. São Paulo: Graal, 1990. 
UZEL, Marcos. O Teatro do bando - negro, baiano e popular. Vila Velha. - Salvador: P555 Edições, 2003. 294 p. - (coleção Cadernos do Vila, 2).

Recebido em: 20/01/2015

Aprovado em: 02/07/2015 